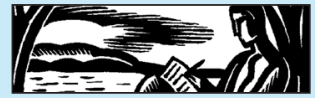

\title{
Buttons: Life Writing from a Small Collection
}

\author{
Rachel Robertson
}

Curtin University

\section{ABSTRACT}

This essay explores the role of everyday objects in life writing, using the example of a collection of buttons. Writing as bricoleur, and influenced by thing theory, I follow a digressive path and wonder how key aspects of life writing, such as memory, the body, and identity, are influenced when one writes from and with objects.

Keywords: thing theory, objects, life writing, buttons

Thumbsized, wooden, with two holes. Three flowers are painted around the central circle: orange, emerald green and white, all with yellow centres. A tiny artwork, a utilitarian object, a remnant of the past? Who knows (now) where and when it arrived in this box.

This button comes from a collection of buttons that I inherited. Like many people, my mother collected spare and discarded buttons, just in case they were needed in the future. Even as a child, I remember these five boxes containing buttons and graded by size. They were always full, which now strikes me as bizarre. Our family was large I suppose- two parents, five children-but to have so many spare buttons seems odd. As children, we played with these buttons, pulling them out and looking at the shapes and colours and then putting them back into the tins. Years later, in another country, when my mother was old, my own son did the same.

After my mother died and my siblings and I were sorting through all her possessions and finding homes for them, we asked my sister-in-law if 
she would like anything of my mother's. After a fruitless search to find something she wanted, she eventually said, 'I do like those old tins; we could use them for something.' There was a shocked inhale of breath at this; none of my siblings could imagine these tins being used for anything except buttons. She was politely persuaded to take something of greater financial worth-but less value.

And so my son and I have these boxes and the buttons, because they mean something, though I'm not sure what as I sit down to write this essay, three years after my mother's death, and almost 50 years after I first encountered the buttons. I have been researching how everyday objects are used in life writing, and how I can use such objects in my own autobiographical essays. It is easy to see how valuable heirlooms or significant family collections may inspire autobiography, as in Tim Bonyhady's Good Living Street and Edmund de Waal's The Hare with Amber Eyes, but how do ordinary, utilitarian things like kitchen cutlery or paperback books or tins of buttons inspire and shape autobiographical writing? Looking at the everyday objects I inherited made me ponder how some of the key aspects of life writing - like memory, identity, body-might be understood differently when looking through the lens of this everyday object, the button. In this essay, I follow the lead of Sherry Turkle, adopting a bricolage method (as described by Lèvi-Strauss) of writing about, with, and through things, following the 'evocative object' and 'manipulating a closed set of materials to develop new thoughts' $(2007,308)$.

\section{MEMORY}

A matching pair: one with zebra swirls of black and pink lines on a black base, the other with pink and black lines on a pink base. Flashy twins, born in the sixties perhaps, both mirroring and fighting. What garment once held this couple in symbiotic separation?

Immediately I opened the first tin, I noticed three large grey buttons and found myself returned to my first days at school as a four year old, standing very close to my mother in her grey coat. The coat was soft and furry and I would stroke the fake nylon fur as a way to comfort myself and deal with my fear of going to school. Some days, she would let me hold her arm as we walked there, coming out of her dark mood enough to talk and reassure me.

Another moment of emotion revisits me when I see a turquoise, red and white button. This, I realise, is from a dress my oldest sister wore in about 1970 when she left home to go to university. I was my sister's pet, ten years younger than her. In the turmoil of our family life, she would keep a 
protective eye on me. The strange feeling I have when I see and touch this button combines this sense of special support with the loss I felt when she left home for months at a time when I was only eight years old.

Then there is a brown button that I recognise from one of my own dresses. Having two older sisters meant I wore a lot of hand-me-down clothes, but sometimes I got a brand new dress, chosen just for me. I remember now how my uncle once told me I looked nice in my new brown and white checked dress with the very smart belt, and so I loved and wore it until it was ridiculously tight on me.

So many of these buttons summon moments of affect, fragments of family life that were long forgotten until I opened these tins. They are like photograph albums, but the snapshots they hold have a quirky angle. Unlike photographs, which make me feel outside the image I am viewing, the mental images and feelings that these buttons arouse insert me right inside my younger self, looking outwards, just like the face of a button on a dress.

The buttons straddle a range of decades. The Bakelite buttons take me back to those 1920s and 30s Bakelite items we once had and discarded and that are now collectable vintage. Glass buttons give way to Lucite and other forms of plastic, some of them reminding me of the melamine plates we used as children, how these 'unbreakable' items would actually break if dropped on our stone kitchen floor and how I once put one under the grill causing bubbles to form around the edge, and creating a terrible smell.

Plain clothes in the 1940s were often decorated with colourful buttons like some of the ones here, a cheap way to add style. A plaited brown leather button speaks of the 1950s. The bright bold colours of pop art are from the 1960s, some of them covered with material to match a dress or top. The round black ball-like buttons from the early 1970s were still considered very smart when I was a teenager, echoing space-race design on a matching skirt and top I owned. And in the boxes are some gold buttons that I think must be from a woman's power dressing suit of the 1980 s, perhaps even from the expensive green linen suit I wore to my first professional job.

\section{IDENTITY}

Scallop-edged and scuffed, faded semi-opaque plastic, a hard-working, almost broken thing. Imagine a pale blue broderie anglaise night-dress worn in summers by a young girl sixty years ago. Later used by her children for dress-ups: 'I'll be the queen this time,' demands the youngest, pulling old finery over her head. 
Many families have tins of buttons, often from parents or grandparents. All the same, it is surprising that my mother kept so many for so long. She detested sewing and all other domestic chores or tasks that were then the role of women. Most of her life she had a paid job and she disliked taking career breaks to have her five children. She would bitterly complain if she ever had to mend an item of clothing or sew on a loose button. How strange that she bothered to keep all these buttons when she was so adamantly non-domestic.

Why did my mother keep hundreds of ordinary, non-valuable buttons and what uses did she put them to? I ask my sisters this question. None of them know why our mother had so many buttons. 'They were always there,' says one sister, 'I never thought about why.' It's only now that the buttons are separated from their original owner that we notice the oddity of my mother keeping so many and keeping them so long. She had five children to clothe, of course, but even so, it seems an excessive collection to hoard.

'It's about category,' says one sister. 'Putting things in boxes, ordering by size, it makes chaos manageable.' We like this theory, because we know my mother, as a mathematician, was a deeply logical thinker. Nonetheless, it flies in the face of the rest of our family home, which was chaotic much of the time and in which things often strayed from their rightful place.

My oldest sister tells me that our mother used to hang buttons on a thread and then remove one each evening as a way of counting down to an exciting event, like the end of the school term or a special holiday. None of the rest of us remember this, so I assume that it was one of those things that parents only do with their first born.

My youngest sister says that she learned basic arithmetic from my mother placing the buttons on a table in particular formations: three buttons in a row and then another three helping my sister to understand that three plus three equals six. I'm amazed to hear this, as I don't remember any arithmetic-button games at all, and I'm only two years older than her. Did my mother neglect to teach me this, or have I just completely forgotten it? My sister and I are talking over dinner in a tapas restaurant, with plenty of wine and laughter. An hour later, my sister says, 'oh, look, I must have lost a button,' holding up a little metal button shaped like the top of a screw head. After we've both checked our clothes and see no missing buttons, I realise that it is actually part of the drinks menu that has come apart, not a button at all. 'Which makes me think,' says my sister, 'you haven't asked where all the button holes are. You know mama taught us how to make a button hole by using blanket stitch around the edge, don't you?' Again, I have no memory of learning this from my mother. 'I'm not searching for lost holes to go with the buttons,' I say. 'Call yourself a researcher...' jokes my sister. 


\section{BODY}

Square, translucent, scored with double lines across the diagonal. Sharp-edged and masculine, neat not dressy. But why square? Was it designed for a man's shirt, or cuff perhaps?

At fifteen, I found myself sitting on a single bed in a college room with a man as he slowly undid the small white buttons on my school blouse. His hands shook a little (he was a man-boy I now realise, only eighteen himself) and he fumbled the task. Neither of us smiled; we were both too nervous. One of the buttons popped off my blouse, out of his hands and on to the brown carpet. There it lay for the rest of that confused evening, as we tried to find a balance between reticence and desire. When he drove me home at $11 \mathrm{pm}$, I remembered the lost button, and placed my hand over my school jumper, covering the empty space on my blouse all the way home.

Buttons are of the body, actors in the creation and curation of a body's shape. While originally carved from shell or bone as an ornament, in the twentieth-century, the button became a way to show off the body, both male and female (Stewart 2012). Buttons literally work to create the shape of the body in clothes, to highlight certain aspects, to disguise or hide others. They may be deeply sexy: the row of buttons down the back of a dress, the button on the fly of a man's trousers, the top button of a shirt... All are there to suggest unbuttoning as much as buttoning. The unbuttoning of another's clothing is profoundly intimate and bodily. We do it only for those dependent on us and those with whom we have intimate, usually sexual, relationships.

A button may also help us shape our own image, aiding our curation of self. Using vintage buttons, for example, may project a particular type of hipster image, whilst wearing clothes with missing buttons may be read as a lack of self-care, laziness, or poverty. In my first year of primary school, I yearned for a dress with cute ladybird buttons, like my friend Helen wore. Her mother was a 'stay at home' mother and sewed all her dresses, adding frills and lace as well as buttons. I sat in class hoping that one of the ladybirds would fall off Helen's dress so that I could take it and keep it in secret. This, I knew, was a shameful thought to have, especially as I considered Helen my best friend. But the envy was strong. When I visited after school, Helen's mother, Mrs L., seemed to me so warm and kind, offering us cake, and asking Helen and me about school, interested in all that we had to say. I had seen Mrs L. noticing the strange pocket that my mother had manufactured out of calico and elastic and safety pinned to 
my dresses so that I always had a handkerchief available (being a chronic hay fever sufferer). Seeing Mrs L.'s face made me embarrassed of this 'pocket'; Helen would never have worn such a thing. This was the glaring difference: Helen had ladybird buttons (six of them) and I had a safety pin. And in all my mother's button collection, there were no buttons as adorable or desirable as the ladybirds.

From the vantage point of many years, I can see the link between the six-year-old feeling ugly in her clothes and the fifteen-year-old desperate for a young man to consider her attractive, willing to accommodate his desires. The two lost buttons-the ladybird button that never fell off Helen's dress and the school button that was never returned to me-reflect a complex picture of bodily desire and shame. This picture may seem dated, and yet I see similar complexities in young people now, as they navigate the button of the contemporary age: the smartphone button that seems so interwoven with memory, desire, and the bodily self. The button, I suggest, is clearly one of Turkle's (2007) 'evocative objects', bringing together emotion and intellect, reminding us of the blurry lines between self and other.

\section{WILD THINGS}

Walnut-coloured, thick, with embossed thistles on the front and a single tunnel for thread at the back. A little scratched, a little dowdy, an everyday thing of its time. And yet now, the thistle motif gives it gravitas and a home. Surely this button was made in Scotland in the mid-twentieth century?

My mother's collection of buttons sit on a shelf in my house in their original five tins. Occasionally I use them, though never yet for their original purpose as a fastener for clothes. I have made a bracelet for one sister from some of the most attractive buttons, and earrings for myself. My son and I use the buttons every few weeks at the suggestion of his psychologist. We close our eyes and try to clear our minds of all thoughts and for each thought we notice, we move one button into a little pile beside us. At the end of the two-minute silence, I have a small pile and my son has a large pile. Over time, the piles do not reduce (which is the goal of the exercise) - we are both too 'thinky' it seems-but at least we enjoy the touch of the buttons on our hands as we return them to their tins.

Buttons have become to me what Sherry Turkle (2007) describes as 'provocations to thought', and to writing (5). Thinking through buttons has made me question my memories, my understanding of my mother's identity, her relationship to me, and my relationship with my own body as child and adolescent. In my experiment of using everyday objects as 
triggers for autobiographical writing, I find I am continually presented with the unknown, the absent, and the forgotten in rather more concrete ways than I expected.

To use buttons as jewellery or as a writing trigger is to treat them more like things than objects. In this I refer to Bill Brown's (2001) distinction between objects, which are what the human subject makes of things (for example, a button is an object we use to keep our coat closed) and things, which precede and exceed objects, and which may also result from our misuse of them (for example, a button as cognitive behavioural training tool). As Breitbach (2011) says of Brown's thing theory, 'In other words, every humble object, at any time, might reveal itself to be a "wild thing," really' (34). My mother's buttons have now become wild things in my writing life.

In Peter Schwenger's (2001) discussion of the opposition of word and thing, he demonstrates how there is always 'an unknowable otherness to the thing,' even if it is named as object (101). If, as Schwenger asserts, 'there is a murder of the thing by the word,' still 'the word that replaces the thing is absence as much as presence' (113). Describing these buttons, guessing their age and provenance, and retrieving (or it could be imagining) new memories of the past, enacts a similar replacement. The substance of the physical object seems to disappear under the weight of words, memories and imagination. The object becomes uncanny and a kind of haunting occurs as people and places from the past rise up like invisible dancing partners.

As bricoleur, I have probably spent too long playing with my mini collection, and projected too much onto these small mute buttons. But it seems to me that examining objects, even insignificant objects like buttons, can offer the life writer new angles for exploring memory, the body, and identity. The tins of buttons have acted as 'evocative objects,' causing me to think and write about life writing from a slightly skewed perspective, recognising how objects mediate human relations. I have found, as Alice Blackhurst suggests, that non-human objects can be 'a springboard to subjective insight' $(2015,435)$. I am hoping that pursuing this approach may mean that, one day, I will learn to write wholly from and with things instead of self.

Deep purple-brown plastic, with a domed top that is textured to look like beaten metal. Four large holes for serious attachment to a coat. One edge must have seen more sun for it has faded to a mottled blue, like a bruise under the chin. It fits neatly into the centre of my palms, smooth and flat on one side, warmly faceted on the other. It reminds me of ... something, but I don't know what. For how can a button be anything other than a button? 


\section{WORKS CITED}

Blackhurst, Alice. 'From Life Writing to Thing Writing: François Bon's autobiographie des objets.' French Cultural Studies 26:4 (2015) 426-438, doi: 10.1177/0957155815597423. Date accessed: 7 June 2020.

Bonyhady, Tim. Good Living Street. Melbourne: Allen \& Unwin, 2011.

Breitbach, Julia. 'The Photo-as-thing.' European Journal of English Studies 15:1 (2011) 31-43, doi: 10.1080/13825577.2011.553895. Date accessed: 6 December 2019.

Brown, Bill. 'Thing Theory.' Critical Inquiry 28:1 (2001) 1-22.

de Waal, Edmund. The Hare with Amber Eyes. London: Vintage, 2011.

Schwenger, Peter. 'Words and the Murder of the Thing.' Critical Inquiry 28:1 (2001) 99-113.

Stewart, Jude. 'The Simple, Humble, Surprisingly Sexy Button: A visual history.' Slate, 14 June 2012, http://www.slate.com/articles/life/design/2012/06/button_history_a_visual_tour_of_button_design_through_the_ages_.html. Date accessed: 6 December 2019.

Turkle, Sherry, (ed). Evocative Objects: Things We Think With. Cambridge, MA: The MIT Press, 2007.

\section{ABOUT THE AUTHOR}

Rachel Robertson is senior lecturer and Deputy Head of the School of Media, Creative Arts and Social Inquiry at Curtin University, Western Australia. She is the author of the memoir Reaching One Thousand and other creative works as well as scholarly publications. Her research interests include life writing, disability studies, creative writing and Australian literature. E-mail: R.Robertson@curtin.edu.au. 